JURNAL RISET PENDIDIKAN MATEMATIKA

Volume 3 - Number 2, November 2016, (150 - 161)

Available online at http://journal.uny.ac.id/index.php/jrpm

\title{
DEVELOPING MATHEMATICS LEARNING SET FOR SPECIAL-NEEDS JUNIOR HIGH SCHOOL STUDENT ORIENTED TO LEARNING INTEREST AND ACHIEVEMENT
}

\author{
Ai Sadidah $^{1} *$, Ariyadi Wijaya ${ }^{2}$ \\ 12 Department of Mathematics Education, Universitas Negeri Yogyakarta. Colombo Street No. 1, \\ Karangmalang, Yogyakarta 55821, Indonesia \\ * Coressponding Author. Email: aisadidah@gmail.com,Telp: +6281297973151 \\ Received: $13^{\text {th }}$ September 2016; Revised: $5^{\text {th }}$ October 2016; Accepted: $3^{\text {rd }}$ November 2016
}

\begin{abstract}
This study aims to produce a mathematics learning set for special-needs students (mathematical learning disability and mathematically gifted) of Junior High School Grade VIII Second Semester oriented to learning interests and achievement which is valid, practical, and effective. This study was a research and development study using the Four-D development model consisting of four stages: (1) define, (2) design, (3) develop, and (4) disseminate. The quality of learning set consisting of the following three criterions: (1) validity, (2) practicality, and (3) effectiveness. The data analysis technique used in this study is a descriptive quantitative analysis. The research produced learning set consisting of lesson plans and student worksheets. The result of the research shows that: (1) the learning set fulfill the valid criteria base on experts' appraisal; (2) the learning set fulfill the practical criterion base on teacher's and students' questionnaire, and observation of learning implementation; (3) the learning set fulfill the effectiveness criterion base on learning interest and achievement.
\end{abstract}

Keywords: research and development, learning tools, special-needs student, interests, learning achievement.

How to Cite: Sadidah, A., \& Wijaya, A. (2016). Developing mathematics learning set for special-needs junior high school student oriented to learning interest and achievement. Jurnal Riset Pendidikan Matematika, 3(2), 150-161. doi:http://dx.doi.org/10.21831/jrpm.v3i2.10866

Permalink/DOI: http://dx.doi.org/10.21831/jrpm.v3i2.10866

\section{INTRODUCTION}

Mathematic is a universal science that provides benefits of human-life and becomes the foundation of modern technology development. The recent fast-growing development of technology, information and telecommunication ruled by mathematics development. Furthermore, mathematic plays a vital role in various science disciplines and advancing the human thought power. Therefore, all students should get chances and necessary supports to learn the essential mathematics through deepening and understanding (NCTM, 2000, p.5).

Attachment III of Ministerial Regulation No. 58/2014 mentions that mathematic should be provided to all students to equip them with logical, analytical, systematic, critical, innovative and creative thinking abilities, including cooperation ability. Such competences needed to enable students to master the ability of obtain- ing, managing and utilising information for a better life in the constantly changes, uncertainties, and highly-competitiveness situations. During the mathematic learning implementation, it is expected that the students are able to sense its advantage (Kemdikbud, 2014a). Mathematical competence or ability is a part of life competence that should be owned by student particularly in reasoning, communication and daily problem solving development. Individual needs to master mathematic in certain levels. Such an individual mastery is not a mathematical competency as a science, but as a matter of mathematical literacy needed to understand the universe as well as to be succeed in his or her life and endeavour.

Considering such importance, therefore, mathematical competence and understanding is every student's need, including those with special needs student. The National Council of Teachers of Mathematics (NCTM) in the Prin- 


\section{Jurnal Riset Pendidikan Matematika, 3 (2), November 2016 - 151}

Ai Sadidah, Ariyadi Wijaya

ciple and Standards for School Mathematics highlighted the importance of equal opportunity and support to be provided to all students, including to those students with special needs in achieving the substantial understanding from the importance of mathematic. NCTM further contends that one of school mathematical principles is an equity. It emphasises that mathematic education needs to provide an opportunity and solid support to all students, without distinguishing the individual characteristics, backgrounds, or physical limits experienced by student. Therefore, school and education system shall accommodate the special needs of some students to promote access and achievement for all students (NCTM, 2015, p.5, p.11, p.12, p.13).

In line with the NCTM standards and principles, the Indonesia Law No. 20/2003 on the National Education System, Chapter IV Article 5 (1) states that every citizen have an equal right to earn a quality education. The state support on the quality education rights to all students also implicitly mandated by Chapter V Article 12 of Law 20/2003 that states that all students at all level have a right to earn education services based on his or her talent, interest and competence (Republik Indonesia, 2003). Thus, education services provided by schools including the mathematic teachers shall pay attention on the student characteristics including the special needs of some students. It aims to ensure that special need students do not experience learning difficulties comparing to other students.

Special needs-student has a wider spectrum and definition. Blackhurst \& Berdine (1981, p.9), Kirk \& Gallagher (1989, p.5), Hallahan \& Kauffman (Mangunsong, 2014, p.3), and Heward (2013, p.7) categorise special-needs student as a differentiated-student from students in general in one or more following areas: (1) mental retardation, (2) learning disability or attention disorder, (3) emotional or behavioural disturbances, (4) physical barriers, (5) communication barriers, (6) autism, (7) traumatic brain injury, (8) hearing barriers, (9) vision barriers or (10) special gifts or talents.

Besides above categorisations, Van de Walle, Karp \& Bay-William (2014, p.101) added the cultural differences, language differences, and unmotivated or need to build resilience as categories of special-needs student. In line with such categorisation, Ministerial of Education and Culture Regulation No. 157/2014 groups special-needs students into two cate- gories: students with learning disabilities and gifted or talented students. The difficulties level in student learning process participation can be caused by characteristic, physical, emotional, mental, intellectual and/or social disorders (Kemdikbud, 2014b). Considering the wide coverage of special-needs student, this study focused on special-needs students with learning disability category and gifted or talented students in a regular classroom. More specifically, in mathematics, learning difficulties and talent that become a focus of this study are mathematical learning disability and mathematically gifted.

Mathematical learning disability student is a student with special difficulties with perceptual and cognitive processing (Van de Walle, Karp \& Bay-William, 2014, p.104), experienceing difficulties in a mathematical calculation (Hallahan \& Kauffman in Mangunsong, 2014, p.203), demonstrating cognitive and behavioural characteristics that prevent the mathematical performance, and is characterised by the lack of systematic approach in problem solving (Montague \& Jitendra, 2012, p.483-484). Meanwhile, mathematically gifted is a student with high thinking performance and mathematical understanding; manipulating symbolic materials faster and effectively (Blackhurst \& Berdine, 1981, p.470); making connections (Rotigel \& Fello in Van de Walle, Karp \& Bay-William, 2014, p.115); solving problems with various resolution strategies (Clark; Davis, Rimm, \& Siegle; Maker; Piirto in Heward, 2013, p.459); ability in utilising the visualisation; have a spatial conceptualisation; have strong ability in generalisation, abstraction, analysis and synthesis (Krutetskii in Grinstein \& Lipsey, 2001, p.284).

To be more successful in schools, mathematical learning disability and mathematically gifted students need a systematic instruction program designed to consider the individual needs. The individual approach does not mean that every student has to be individually explained or attend in a small group, but students obtain daily instruction based on their respective needs (Mercer \& Mercer, 1985, p.5). Instruction designed based on the individual needs is known as differentiated instruction. Lack of teacher's understanding on different characteristics and needs of every students might cause the lessons do not optimally achieve its expected goal. Special needs-student's emphasis (mathematical learning disability and 
mathematically gifted) in this study focuses on special characteristic of students that need teacher's attention to enable every student's needs facilitated in learning. It is to enable all students do not experience obstacles due to such special characteristics during learning process.

Based on the researcher's observation to date, the majority of schools provide the same treatment and classical to all students regardless below or above average in which students actually have different needs. The next problems are then: (1) below average students whose learning speed is below average will always be left behind in participating the lessons, and (2) above average students will be bored since they need to adjust with the other students whose learning speed is on average or below average. It is in line with what has been contended by Bender (2011, p.60) in which learning that do not consider the varied students' competencies will lead students with high competencies, including gifted students, will be bored and students with lower competencies, including learning disabilities, will be left behind since do not acquire the required basic skills. So far the categorisation of student competencies is based on grade of minimum completion criteria or Kriteria Ketuntasan Minimal (KKM). It can be regarded as a teacher's good effort to respect students' heterogeneity in the classrooms made it possible the designed lessons can accommodate such diversities. However, the researcher has not found any learning set developed by teachers that deliberates student's characteristics including those KKM-oriented category.

Categorisation of students based on KKM orientation will facilitate teachers in recognising the students' competencies based on merely academic achievement. The KKM oriented categorisation, however, is more result-oriented and ignore the process through. So that the student's special-characteristics that have to be main focus of consideration frequently missed from the attention. During the learning process, the lack of information about the student's special characteristics cause teacher found difficulties in determining which students that need support (scaffolding) and which students that need challenge (challenging).

In a learning process, teacher is required to be able to use learning media and other lesson resources that are relevant to students' characteristics and the teaching subjects to achieve the determined learning goals. As an effort to achieve the learning goals, student's worksheet
(LKS) can serve as a learning media and resource. However, based on discussion with mathematic teachers in a school located in Garut Regency of Indonesia showed that there are only few teachers who develop student's worksheet (LKS) that meets with the special-needs students. Generally, the student's worksheet is utilised to be applied to all students without considering the special needs of students.

From a psychological aspect, one of student characteristics that teacher needs to pay attention with is interest. Interest is believed to contribute to a student's success in understanding mathematics. According to Nunnally (Gable, 1986, p.8) interest is a preference to certain work activities. Students with high interests tend to actively participate in the learning process. In contrary, students with lower interests tend to withdraw from active learning participation, that may produces boring or less enjoy the attended learning classes. The teacher's ability to identify the interest of every individual students will be a critical foundation to determine how such interests managed and projected to encourage the achievement of an optimal learning goal.

Based on field observations, students' interest towards learning mathematics is still relatively low. It is characterized by a lack of students' attention in participating the mathematics learning. During the learning, some students were talking with a friend, some others are indifferent and ignore the given assignment, less-actively involved in group discussions and some students feel bored with the mathematics learning because of found it less-important to be studied.

In addition to interest, the reality on the ground shows that student's mathematical achievements are still not in line with expectations. Final Report Determinants of Learning Outcomes Trends in International Mathematics and Science Study, TIMSS 2011 (Balitbang Kemendikbud, 2012, p.30) mentions that the average score of student's mathematics achievement in Indonesia in 1999, 2003 and 2007 were 403, 411 and 405 respectively. Meanwhile, the Research Department of the Ministry of Education and Culture of Indonesia (Kemendikbud) (2012, P.50) states that the average score of student's mathematics achievement in Indonesia in 2011 was 400.97. From the average score achievement obtained in 2011, we can see that it is three points lower compared to 1999, eleven points lower compared to 2003 , and five points 
lower compared to 2007. Thus, from the four periods above, 2011 is the lowest achievement compared to the three previous periods. Shall the data rating to be applied, the TIMSS study findings put Indonesia into position $34^{\text {th }}$ of the 45 surveyed countries. Meanwhile, the TIMSS study findings in 2012 Indonesia was ranked $38^{\text {th }}$ out of 63 countries that delegate their students in the test. This indicates that the achievement of Indonesian students in math is decreased (Kartika, 2013).

The reports of junior high school national examination of academic year 2014/2015 in Garut Regency shows that the level of student's absorption capacity on mathematics is still low. Examination subject about geometry flat sides that are part of the subject of junior high school's math for the second semester of VIII grade is one competence categories tested in the national examination. On the ability to understand the nature and elements of geometry and apply them in problem solving, the students' absorption capacity for Garut Regency in National Exams academic year $2014 / 2015$ is $50.59 \%$. This percentage is still lower than the absorption capacity of the province $(51.12 \%)$ and national absorption capacity $(51.37 \%)$. State Junior High School (SMPN) 1 Cisurupan, one of junior high schools in Garut Regency, SMPN 1 Cisurupan, one of the junior high schools in Garut Regency, to the report of the national exams in academic year 2014/2015 showed absorption capacity of $46.48 \%$ on the ability to understand the nature and elements of geometry and apply them in problem solving. In other words, student achievement in mathematics is still not in line with expectations.

Based on the above explanation, the researcher motivates to develop the mathematical learning set for the second semester of grade VIII of junior high school's students with special needs (mathematically learning disability and mathematically gifted) oriented to the interests and learning achievements in order to obtain a valid, practical and effective learning set.

\section{METHOD}

This study is a research and development study in the field of education. Research development refers to the Four-D development model that consists of four steps: (1) define; (2) design; (3) develop; (4) disseminate (Thiagarajan, Semmel, \& Semmel, 1974, p. 5). The quality of products consists of three follow- ing criteria: validity, practicality, and effectiveness (Nieveen, 1999; p.125). The products developed in this study is a learning set in the form of lesson plan (RPP) and the Student's Worksheet (LKS).

The study is undertaken in State Junior High School (SMPN) 1 Cisurupan, Garut Regency, West Java province, in March to April 2016.

The subject of the limited trials are seven students of grade VIII E of SMPN 1 Cisurupan Garut which represents the category of mathematically-gifted student (1 person), non-special needs-students ( 3 persons), and mathematicallylearning disability students ( 3 persons). Meanwhile, the subject of field trials are two teachers as presenter and observer respectively and 35 students of grade VIII of SMPN 1 Cisurupan of Garut Regency with 5 special needs-students for mathematically gifted category 1 and 4 students with mathematical learning disability.

\section{Procedures of Research}

Development procedures of the research refer to development model called Four-D as shown by Figure 1 below.

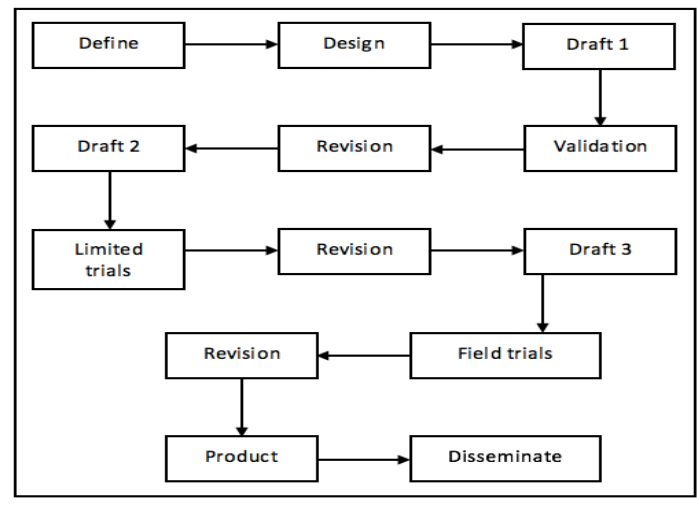

Figure 1. Research Flow

\section{Data, Instrument, and Data Collection Technique}

The type of data collection in this study is a qualitative and quantitative. They aimed at obtaining the description of quality of developed products. The qualitative data obtained from the feedback and suggestions from validators, teachers, and students. The quantitative data obtained from the scores of expert validation of the feasibility of the developed product in the forms of lesson plans (RPP) and student's worksheets (LKS); RPP appraisal scores by the teacher; LKS appraisal scores by teachers and students; observation data on learning implementation; 
and data of interest questionnaires and tests of student achievement.

The instrument being applied in this study are: (1) RPP and LKS validation sheets; (2) teacher's practicality appraisal sheets; (3) student's practicality appraisal sheets; (4) learning implementation observation sheets ; (5) interest appraisal instruments; and (6) learning achievement appraisal instrument.

Data collection techniques in this study consist of questionnaires, observation, and measurement through the test. The questionnaires technique was applied to collect the validation data on learning set from expert validators, appraisal data on learning set practicality by teachers and students, as well as appraisal data on student interest. Observation technique utilised to gather the data on learning implementation. Testing technique used to collect data on student's competency achievement.

\section{Data Analysis Technique}

The data analysis in this study aims to answer research questions on the validity, practicality, and effectiveness of the developed products. Feedback, comments and suggestions were analysed qualitatively, which is then utilised as the inputs to revise the developed product. Meanwhile, the data obtained through the validation sheets, teacher's appraisal practicality sheets, student's appraisal practicality sheets practicality, and interest appraisal that was analysed through statistical descriptive.

Data in the form of scores are converted into qualitative data with five categories. The reference of scores conversion into five categories presented in the following table.

Table 1. Category of Conversion from Quantitative Data to Qualitative Data

\begin{tabular}{cc}
\hline Interval & Category \\
\hline $\bar{M}>M_{i}+1,8 S d i$ & Very good \\
$M_{i}+0,6 S d i<\bar{M} \leq M_{i}+1,8 S d i$ & Good \\
$M_{i}-0,6 S d i<\bar{M} \leq M_{i}+0,6 S d i$ & Fair \\
$M_{i}-1,8 S d i<\bar{M} \leq M_{i}-0,6 S d i$ & Poor \\
$M \leq M_{i}-1,8 S d i$ & Very poor \\
\hline
\end{tabular}

(Widoyoko, 2011, p.238)

Notes:

$\bar{M}_{i}=\frac{1}{2}$ (ideal maximum score + ideal minimum score)

$S d i=\frac{1}{6}($ ideal maximum score - ideal minimum score)

Wherein: $M=$ empirical score

$$
\bar{M}_{i}=\text { ideal mean }
$$

$$
S d i=\text { ideal standard deviation }
$$

Analytical Technique of Data Validity

The validity instrument uses a five-point scale. Analysis of data validity is through the following steps: (1) summing the total validation score from both validators, (2) determining the validity score average, and (3) categorising validity score average into 5 categories as shown in Table 1.

The ideal minimum score, ideal maximum score, $\bar{M}_{i}$, and $S d i$ of learning set validity (RPP and LKS) is shown in Table 2 below.

Table 2. Ideal Minimum Score, Ideal Maximum Score, $\bar{M}_{i}$, and $S d i$ for RPP validity

\begin{tabular}{ccccc}
\hline $\begin{array}{c}\text { Total of } \\
\text { questions }\end{array}$ & $\begin{array}{c}\text { Ideal } \\
\text { minimum } \\
\text { score }\end{array}$ & $\begin{array}{c}\text { Ideal } \\
\text { maximum } \\
\text { score }\end{array}$ & $\overline{\boldsymbol{M}}_{\boldsymbol{i}}$ & $\boldsymbol{S d i}$ \\
\hline 35 & 35 & 175 & 105 & 23,3 \\
\hline
\end{tabular}

Table 3. Ideal Minimum Score, Ideal Maximum Score, $\bar{M}_{i}$, and $S d i$ for LKS Validity

\begin{tabular}{ccccc}
\hline $\begin{array}{c}\text { Total of } \\
\text { questions }\end{array}$ & $\begin{array}{c}\text { Ideal } \\
\text { minimum } \\
\text { score }\end{array}$ & $\begin{array}{c}\text { Ideal } \\
\text { maximum } \\
\text { score }\end{array}$ & $\bar{M}_{\boldsymbol{i}}$ & $\boldsymbol{S d i}$ \\
\hline 23 & 23 & 115 & 69 & 15,3 \\
\hline
\end{tabular}

From Table 2 and Table 3 obtained an interval to determine the validity category of learning set as shown by Table 4 .

Table 4. Validity Category of Learning Set

\begin{tabular}{ccc}
\hline Validated set & Interval & Criteria \\
\hline RPP & $\bar{M}>147$ & Very good \\
& $119<\bar{M} \leq 147$ & Good \\
& $91<\bar{M} \leq 119$ & Fair \\
& $63<\bar{M} \leq 91$ & Poor \\
& $\bar{M} \leq 63$ & Very poor \\
\hline LKS & $\bar{M}>96,60$ & Very good \\
& $78,20<\bar{M} \leq 96,60$ & Good \\
& $59,80<\bar{M} \leq 78,20$ & Fair \\
& $41,40<\bar{M} \leq 59,80$ & Poor \\
& $\bar{M} \leq 41,40$ & Very poor \\
\hline
\end{tabular}

Learning set is valid only when the minimum appraisal criteria of RPP and LKS are in "Good" category.

Analysis Technique of RPP Practicality Data based on Teacher's Appraisal

Data analysis by teachers undertook through the following steps: (1) summing the total appraisal scores of the two teacher (presenter and observer), (2) determining the average practicality scores, and (3) categorising 
the average practicality scores into 5 categories as per Table 1 .

The ideal minimum score, ideal maximum score, $\bar{M}_{i}$, and $S d i$ of RPP practicality based on teacher's appraisal is shown in Table 5 below.

Table 5. Ideal Minimum Score, Ideal Maximum

Score, $\bar{M}_{i}$, and $S d i$ for RPP practicality

\begin{tabular}{ccccc}
\hline $\begin{array}{c}\text { Total of } \\
\text { questions }\end{array}$ & $\begin{array}{c}\text { Ideal } \\
\text { minimum } \\
\text { score }\end{array}$ & $\begin{array}{c}\text { Ideal } \\
\text { maximum } \\
\text { score }\end{array}$ & $\overline{\boldsymbol{M}}_{\boldsymbol{i}}$ & $\mathbf{S d \boldsymbol { i }}$ \\
\hline 5 & 5 & 25 & 15 & 33,3 \\
\hline From & Table & 5 & obtained an interval to
\end{tabular}

determine the practicality category of RPP based on teacher's appraisal as shown in Table 6.

Table 6. Categorisation of RPP Practicality based on Teacher's Appraisal

\begin{tabular}{cc}
\hline Interval & Criteria \\
\hline $\bar{M}>21$ & Very good \\
$17<\bar{M} \leq 21$ & Good \\
$13<\bar{M} \leq 17$ & Fair \\
$9<\bar{M} \leq 13$ & Poor \\
$\bar{M} \leq 9$ & Very poor \\
\hline
\end{tabular}

RPP is practical only if the average of RPP practicality appraisal score at least in "Good" category.

Data Analysis Technique of LKS Practicality based on Teacher and Student's Appraisal

The LKS practicality data analysis based on the teachers and students' appraisals is through the following steps: (1) collecting the data, (2) determining the empirical score from the gathered data for teachers and students' appraisals respectively, and (3) determining the categories of products according to the practicality criteria as shown in Table 1 . The ideal minimum score, ideal maximum score, $\bar{M}_{i}$, and $S d i$ of RPP practicality based on teachers' appraisal is shown in Table 7.

Table 7. Ideal Minimum Score, Ideal Maximum Score, $\bar{M}_{i}$, and Sdi of LKS Practicality based on Teachers' and Students' Appraisals

\begin{tabular}{ccccc}
\hline $\begin{array}{c}\text { Total of } \\
\text { questions }\end{array}$ & $\begin{array}{c}\text { Ideal } \\
\text { minimum } \\
\text { score }\end{array}$ & $\begin{array}{c}\text { Ideal } \\
\text { maximum } \\
\text { score }\end{array}$ & $\overline{\boldsymbol{M}}_{\boldsymbol{i}}$ & $\boldsymbol{S} \boldsymbol{d i}$ \\
\hline 7 & 7 & 35 & 21 & 4,67 \\
\hline
\end{tabular}

Table 7 obtained an interval to determine the practicality category of LKS based on teacher's appraisal as shown in Table 8.
Table 8. LKS Practicality Category based on Teachers' Appraisal

\begin{tabular}{cc}
\hline Interval & Criteria \\
\hline $\bar{M}>29,40$ & Very good \\
$23,80<\bar{M} \leq 29,40$ & Good \\
$18,20<\bar{M} \leq 23,80$ & Fair \\
$12,60<\bar{M} \leq 18,20$ & Poor \\
$\bar{M} \leq 12,60$ & Very poor \\
\hline
\end{tabular}

LKS is practical only if the average of scores of LKS practicality appraisal by teachers and students is at least at "Good" category.

Technique of Data Analysis of Observation on Learning Activity Implementation

Data analysis of observation on learning activity implementation is done through the following steps: (1) collecting the data, (2) determining the learning implementation percentages in every meeting sessions, and (3) determining the average percentages of learning implementation.

Learning set is defined as practical if the average percentage of learning implementation is at least $85 \%$.

Techniques of Data Analysis on Effectiveness based on Learning Interest Appraisal

Effectiveness instrument is reviewed based on the learning interests utilising a fivepoint scale (Likert). Effectiveness data analysis determined by the following steps: (1) summing the total score of appraisal of student's learning interest, (2) determining the average validity score, and (3) categorising the average validity score into 5 categories as shown in Table 1.

The ideal minimum score, ideal maximum score, $\bar{M}_{i}$, and $S d i$ of learning set effectiveness is determined by the appraisal of student's learning interest as shown in Table 9.

Table 9. Ideal Minimum Score, Ideal Maximum Score, $\bar{M}_{i}$, and $S d i$ of the Effectiveness of Learning Set based on Interest Appraisal

\begin{tabular}{ccccc}
\hline $\begin{array}{c}\text { Total of } \\
\text { questions }\end{array}$ & $\begin{array}{c}\text { Ideal } \\
\text { minimum } \\
\text { score }\end{array}$ & $\begin{array}{c}\text { Ideal } \\
\text { maximum } \\
\text { score }\end{array}$ & $\overline{\boldsymbol{M}}_{\boldsymbol{i}}$ & $\boldsymbol{S d \boldsymbol { i }}$ \\
\hline 20 & 20 & 100 & 60 & 13,33 \\
\hline From & Table 9 & obtained an interval to
\end{tabular}
determine the learning set's effectiveness category based on learning interest appraisal as shown in Table 10. 
Table 10. Learning Set's Effectiveness Category based on Interest Appraisal

\begin{tabular}{cc}
\hline Interval & Criteria \\
\hline $\bar{M}>84$ & Very good \\
$68<\bar{M} \leq 84$ & Good \\
$52<\bar{M} \leq 68$ & Fair \\
$36<\bar{M} \leq 52$ & Poor \\
$\bar{M} \leq 36$ & Very poor \\
\hline
\end{tabular}

Learning set is defined as effective if the average score of learning set's effectiveness appraisal is at least in "Good" category.

Technique of Data Analysis on Learning Achievement Appraisal

Learning achievement is defined accomplished individually if students achieve Minimum Accomplishment Criteria or Kriteria Ketuntasan Minimal (KKM) of 75. Learning set is defined effective if student's learning achievement is at least $75 \%$ students reach the $\mathrm{KKM}$, at least $75 \%$ students with mathematical learning disability reach the KKM and all mathematically gifted student reach the KKM.

\section{RESULT AND DISCUSSION}

\section{Development Result}

This study uses a development model called Four-D. Therefore, the development process of mathematics learning set for special needs-students at second semester of grade VIII of junior high school oriented interests and learning achievement can be explained by examining the development procedure of learning set that refers to the development model of Four-D until producing the valid, practical, and effective learning set.

\section{Define Stage}

Learning set development through Four-D development model begins with the define phase. At this stage, the problem analysis is conducted till mathematical learning set for second semester of Grade VIII of Junior High School students with special-needs category mathematical learning disability and mathematically gifted is required. Based on discussions with several math teachers it found that some teachers still apply a classical method to all students regardless below average, average or above average in which actually they have different needs. In other word, the learning implementation has not considered the specificneeds of students that may different one to another. Moreover, in delivering the learning contents the teacher still relay on a lecture method with a reason to adjust the limited time availability with the bulks of lesson materials to be delivered. With such lecture method, the learning is mostly centralized on teachers and, on the other side, students just accept what is being delivered by the teacher. In addition to such a condition, based on the teachers' observation in the classroom, some students are less interested in the subject during the math teaching by teachers. Some of them are less enthusiastic about mathematic, even some others frequently found talking with friends or doing other things while the teaching process such as writing or drawing something that do not correspond to the lesson. Such a condition indicates that the mathematics learning in the classroom is less attractive. This development research uses differentiated instruction learning approach. It is an alternative approach that can be implemented in order to accommodate the students' special needs differentiations.

In addition to the problem analysis as described above, at the define stage an analysis was also conducted to students that includes the characteristics of special-needs students with category mathematical learning disability and mathematically gifted.

Special-needs students in this study were identified through the identification tests of students with special needs developed by the researcher through referring to the characteristics of mathematical learning disability students and mathematically gifted students. All students of grade VIII of SMPN 1 Cisurupan administered a students' special needs identification test. The results of the identification test were analyzed based on the pre-determined criteria. The final results of the test was compared with the results of identification by the teacher through students' track record forms during attending the accomplished mathematic learning. Both identification methods are needed to identify students with special-needs category and non-special needs category. In the specialneeds category, the students' identification also identify students with mathematical learning disability (MLD) and mathematically gifted (MG) categories.

The result of student identification showed that of the nine (9) parallel classes of grade VIII found special-needs students with mathematical learning disability (MLD) of 5\%$15 \%$ in every classes, and mathematically gifted (MG) of $2.8 \%$ in 3 out of 9 classes. Product 
trials conducted in classes with special needs students in mathematical learning disabilities and mathematically gifted categories, which is Class VIII I SMPN 1 Cisurupan Garut. 4 out of 35 students of Class VIII I found with mathematical learning disability (MLD) and one student with mathematically gifted (MG). Therefore, the developed learning set strived to facilitate the special needs of students in the regular class dominated by non-special needs students (regular learning class).

Analyses on material to be delivered (conceptual analysis), development of competence achievement's indicator, and development of the mathematical learning objectives for of the second semester of grade VIII of Junior High School were also conducted in defining stage.

\section{Design Stage}

The next step is a design stage. It is conducted by creating product designs in accordance with the analysis results of the defining stage. At this stage, the appraisal instruments that will be used to evaluate the learning set is developed, which namely include: validity, practicality, and effectiveness. The validity of the learning set measured through the validation sheet of learning set. The practicality of learning set measured through teachers' appraisal sheets, students' appraisal sheet and learning implementation observation sheet. While the effectiveness of the learning set measured through appraisal instruments on the learning interest and achievement.

A media selection was also done at this stage to determine the most appropriate media being used in mathematics learning material delivery. The media selection process is based on the competences achievement indicators, materials, and student characteristics. Based on activity analyzes at the define stage, the selected media to present the learning contents are lesson plan (RPP) with differentiated instruction approach and student's worksheet (LKS) which are divided into three categories according to the characteristics of the identified special-needs students.

The next step is the selection of learning tools format. Based on preliminary-final analysis at the define stage, the developed RPP uses the differentiated instruction approach. In this approach, learning activities focused on the individual activities prior to the group's activities. Individual activities aimed at facilitating the students to achieve the required conditions to conduct group activities. The individual activities were facilitated by student's worksheet (LKS) that developed based on the characteristics of the identified students. It is expected that the group activities can facilitate the students to work together, exchange experiences and information, as well as improve the communication skills.

Based on the student analysis, the student's worksheet (LKS) was developed in three categories, namely: (1) LKS P1 code for students with mathematical learning disability (MLD); (2) LKS P2 code for non-special needs students; and (3) LKS P3 code for mathematically gifted (MG). Meanwhile, based on the conceptual analysis, the worksheet on Geometry Flat Sides was provided for 8 student's worksheets (LKS) for 8 times class meetings.

The differences of characteristics of the developed worksheet briefly presented in the Table 11 as followings.

Table 11. Chacacteristics of the developed worksheet

\begin{tabular}{|c|c|c|c|}
\hline Characteristic & $\begin{array}{c}\text { Worksheet } \\
\text { P1 }\end{array}$ & $\begin{array}{c}\text { Worksheet } \\
\text { P2 }\end{array}$ & $\begin{array}{c}\text { Worksheet } \\
\text { P3 }\end{array}$ \\
\hline $\begin{array}{l}\text { Learning step } \\
\text { assistance }\end{array}$ & Very detail & Detail & Not detail \\
\hline $\begin{array}{l}\text { Problem } \\
\text { solving hint } \\
\text { assistance }\end{array}$ & $50 \%$ & $20-30 \%$ & - \\
\hline $\begin{array}{l}\text { Picture } \\
\text { visualization } \\
\text { assistance }\end{array}$ & $75 \%$ & $30 \%$ & $10 \%$ \\
\hline $\begin{array}{l}\text { Props } \\
\text { assistance }\end{array}$ & $100 \%$ & $50 \%$ & $30 \%$ \\
\hline $\begin{array}{l}\text { Information } \\
\text { provision and } \\
\text { visualization }\end{array}$ & $\begin{array}{l}\text { Information } \\
\text { and } \\
\text { visualization } \\
\text { is provided } \\
\text { as closest }\end{array}$ & $\begin{array}{c}\text { The } \\
\text { provided } \\
\text { information } \\
\text { needs } \\
\text { picture } \\
\text { visualization }\end{array}$ & $\begin{array}{c}\text { The } \\
\text { provided } \\
\text { information } \\
\text { not always } \\
\text { with picture } \\
\text { visualization }\end{array}$ \\
\hline
\end{tabular}

The last step in the design stage is the preliminary designing. The activity at this stage is the development a prototype of learning set that consists of lesson plan (RPP) and worksheets (LKS) based on the results of the defining stage until the format selection stage. The prototype of learning set is hereinafter referred to as Draft 1.

\section{Develop Stage}

The develop stage initiated by developing the learning set in the forms of lesson plan (RPP) and the Student's Worksheet (LKS). Once developed, the next step is experts' validation process. The validation process is done through 
validation sheets that previously appraised by experts. After the validation process, the product was then revised based on the experts' inputs and suggestions. The following process is to conduct limited trials to assess the legibility of the developed learning set. The set that has been validated, revised as per validators' suggestions, as well as tested in limited trials then considered as Draft 2 in which hereinafter to be used in the field trials. The results of field trials were then analyzed to assess the product quality based on practicality and effectiveness criteria. The produced set is then considered as Draft 3. The next step is to analyze the set based on validity, practicality, and effectiveness criteria. Set that meets with valid, practical and effective categories is hereinafter referred to as a final set.

Disseminate Stage

The dissemination of product of mathematic learning set for the second semester of Grade VIII of Junior High School students with special needs oriented to learning interest and achievement was conducted through providing the development product to mathematic teachers in SMPN 1 Cisurupan Garut that has become the location of the trial of the developed set. The advanced dissemination program of the mathematics learning set product was done through the Junior High School Mathematics Teachers' Forum (MGMP) of Garut Regency.

\section{Validity Data Analysis}

Learning set that has been prepared as Draft 1 is then validated by two expert validators. Based on data of expert validation appraisal on the developed learning set, the obtained results are as shown in Table 12.

Table 12. Validity Data Analysis of the Learning Set

\begin{tabular}{cccc}
\hline Set & Average score & Criteria & Validity \\
\hline RPP & 158,5 & VG & Valid \\
LKS & 106 & VG & Valid \\
\hline
\end{tabular}

Note: $V G=$ Very Good

Based on Table 12, learning set that comprises of lesson plan (RPP) and Students' Worksheet (LKS) has met with validity criteria.

\section{Practicality Data Analysis}

The practicality of the developed learning set obtained from the teachers' and students' appraisals on the learning set as well as the percentage of learning activities implementation.
The teachers' appraisal data is utilised to analyse the practicality of the learning set in the forms of lesson plan (RPP) and students' worksheet (LKS).

Data analysis on the results of RPP practicality by teachers showed that the average gained score is 19.5. This score is in a "Good" category and hereinafter concluded that the developed lesson plan (RPP) has met with the practicality criteria.

There are two data on students' worksheet (LKS) being analyzed, namely LKS practicality by teachers and LKS practicality by students. The data analysis of the appraisal results of LKS practicality by teachers showed that the average score is 27. This score is in the "Good" category, and therefore it can be concluded that the developed worksheet has met with practicality criteria based on the teachers' appraisal. For the result of LKS practicality by students can be found in Table 13.

Table 13. Data Analysis on LKS Practicality based on Students' Appraisal

\begin{tabular}{cccc}
\hline $\begin{array}{c}\text { Student's } \\
\text { category }\end{array}$ & $\begin{array}{c}\text { Average } \\
\text { score }\end{array}$ & Criteria & Practicality \\
\hline MG students & 28 & Good & Practical \\
MLD students & 26.75 & Good & Practical \\
non-SN & 28.87 & Good & Practical \\
students & 28.60 & Good & Practical \\
Total & 28
\end{tabular}

Based on Table 13, it can be seen that the results of students' appraisal on the LKS either by mathematically gifted (MG), mathematical learning disability (MLD), or non-special needs (non-SN) students showed that average score above 23.80. These scores are located in "Good" category, therefore can be concluded that the the developed students' worksheet (LKS) has achieved the practicality criteria according the students' appraisal.

Data analysis on learning set based on the learning activities implementation showed the average percentage of learning implementation is $92.90 \%$. Thus, the developed learning set has achieved the practical criteria based learning implementation.

Based on the RPP and LKS practicality analysis as well as the learning implementation, it can be concluded that the developed learning set has achieved the practical criteria.

\section{Effectivity Data Analysis}

The effectiveness of the learning set can be assessed through data analysis on the learning 
interest and achievement's appraisals. The result of students' interest's appraisal can be seen in Table 14 below.

Table 14. Data Analysis on Effectiveness based on Interest Appraisal

\begin{tabular}{cccc}
\hline $\begin{array}{c}\text { Student } \\
\text { category }\end{array}$ & $\begin{array}{c}\text { Average } \\
\text { score }\end{array}$ & Criteria & Effectiveness \\
\hline MG students & 88 & Good & Effective \\
MLD & 77.25 & Good & Effective \\
students & & & \\
non-SN & 74.33 & Good & Effective \\
students & 75.06 & Good & Effective \\
Total &
\end{tabular}

Based on Table 14, it can be seen that the results of students' interest's appraisals of mathematically gifted students (MG), mathematical learning disability (MLD), and non-special needs students (non-SN) showed that the average scores are above 68. These scores are located in the "Good" category so that it can be concluded that developed learning set has achieved an effective criteria based on the interest's appraisal.

The result of students' achievement's appraisal can be seen in Table 15 below.

Table 15. Data Analysis on Effectiveness based on Achivement Appraisal

\begin{tabular}{cccc}
\hline $\begin{array}{c}\text { Student } \\
\text { category }\end{array}$ & $\begin{array}{c}\text { Average } \\
\text { score }\end{array}$ & $\begin{array}{c}\text { The } \\
\text { percentage of } \\
\text { students } \\
\text { achieve the } \\
\text { KKM }\end{array}$ & Effectiveness \\
\hline $\begin{array}{c}\text { MG } \\
\text { students }\end{array}$ & 95 & $100 \%$ & Effective \\
\hline $\begin{array}{c}\text { MLD } \\
\text { students }\end{array}$ & 77.5 & $100 \%$ & Effective \\
\hline $\begin{array}{c}\text { non-SN } \\
\text { students }\end{array}$ & 78 & $93,33 \%$ & Effective \\
\hline Total & 78.43 & $94,29 \%$ & Effective \\
\hline
\end{tabular}

Based on Table 15, it can be seen that the result of students' achievement's appraisal showed that the average students' achievement scores either mathematically-gifted (MG), mathematically-learning disability (MLD), or non-special needs students showed above 75 score as the established minimum accomplishment criteria (KKM) and students who reached the KKM are more than $75 \%$ for all categories.

In addition to the assessment, the validator also provides some suggestions and inputs. The suggestions are being referred by the researcher in order to improve the developed products. Suggestions and improvements of lesson plan being provided by the validator include: (1) improvement on some definitions related with the teaching materials; (2) brief explanation on the differentiated instruction in the learning method section; (3) corrections in some words and symbols writing mistakes; (4) replace the civil servant registration number (NIP) with the student registration number (NIM) as the writer's reference. Regarding with the improvements on the student work sheets, the validator's suggestions include: (1) improvement on some definitions related with teaching materials; (2) improvement of some pictures in order to be better understood by the students; (3) improvement in the symbols writing.

Based on the readability test by the teachers (learning plan and worksheet) and the students (worksheet) the following inputs obtained: (1) Based on the teachers' input, it found that generally the learning plans are good, however time allocation needs particular attention, especially the allocated time for individual activity of students with learning difficulty, group discussion and the presentation of group discussion; (2) Based on the teachers' and students' input, it found that generally the worksheets are good, readable and easy to understand.

Based on the analysis result of the fieldtested learning set, it found that the developed learning set has met with the practical and effective criteria. However, based on the observation during the lessons, there are few aspects that need to be improved in order to give more optimized impact of the resulted learning set for the students and teachers. The needed revision includes the need to provide the worksheet with the cover to prevent it from being broken, to improve the questions or problem statements as well as to improve the mistakes in writing based on the writing standards in Bahasa Indonesia.

\section{CONCLUSION}

Based on the results of research and discussion it can be concluded as follows: (1) the development research has produced the mathematics learning set product for the second semester of Grade VIII of Junior High School students with special-needs oriented to learning interest and achievement, that comprises of lesson plan (RPP) and Students' Worksheet (LKS ); (2) the product of mathematics learning set for the second semester of Grade VIII of Junior High School students with special-needs 
oriented to learning interest and achievement that consists of RPP and LKS, after going through the validation phase, can be concluded that it has met with the validity criteria; (3) the product of mathematics learning set for the second semester of Grade VIII of Junior High School students with special needs-oriented to learning interest and achievement that consists of RPP and LKS after going through the final field trials phase, it can be concluded that the learning set has met with the practicality criteria . It is based on the results of RPP practicality appraisals by teachers that indicate that the product has reached the practicality criteria, and the results of LKS practicality appraisals by teachers and students that indicate that the product has reached the practicality criteria, and the results of observation on the learning implementation that showed that the percentage of learning implementation has reached more that $85 \%$ for each meetings; (4) the product of mathematics learning set for the second semester of Grade VIII of Junior High School students with special needs oriented to learning interest and achievement that consists of RPP and LKS, based on the research it can be concluded that the produced learning set is effective to be used. The effectiveness of the product is reflected from the acquisition of the students' appraisals in the trialed school that showed that more than $75 \%$ of the students have reached the minimum implementation criteria (KKM), $75 \%$ of students with mathematically learning disability have reached the KKM 75, and all the mathematically-gifted students have reached the KKM 75. Likewise, the results of learning interest's appraisal has reached the scores that met with the effectiveness criteria.

\section{REFERENCES}

Balitbang Kemendikbud. (2012). Final report determinants of learning outcomes, trend in international mathematics and science study. Jakarta: Badan Penelitian dan Pengembangan Kementerian Pendidikan dan Kebudayaan.

Bender, W.N. (2011). Differentiated instruction and response to intervention in mathematics. Dalam L. Laud (Eds.), Differentiated instruction in literacy, math, \& science (pp. 57-83). California: Corwin.
Blackhurst, A. E., \& Berdine, W. H. (1981). An introduction to special education. Boston Toronto: Little, Brown and Company.

Gable, R. K. (1986). Instrument development in the affective domain. Boston: KluwerNijhoff Publishing.

Grinstein, L. S., Lipsey, S. I. (2001). Encyclopedia of mathematics education. New York: Routledge.

Heward, W.L. (2013). Exceptional children: An introduction to special education $\left(10^{\text {th }}\right.$ ed.). London: Pearson.

Kartika, H. (2013). Pembelajaran matematika berbantuan software matlab sebagai upaya meningkatkan kemampuan komunikasi matematika dan minat belajar. Tesis Magister, tidak diterbitkan, Universitas Pendidikan Indonesia, Bandung.

Kemdikbud. (2014a). Peraturan Menteri Pendidikan dan Kebudayaan RI, Nomor 58, Tahun 2014, tentang Kurikulum SMP.

Kemdikbud. (2014b). Peraturan Menteri Pendidikan dan Kebudayaan RI, Nomor 157, Tahun 2014, tentang Kurikulum Pendidikan Khusus.

Kirk, S. A., \& Gallagher, J. J. (1989). Educating exceptional children. Boston: Houghton Mifflin Company.

Mangunsong, F. (2014). Psikologi dan pendidikan anak berkebutuhan khusus. Depok: LPSP3.

Mercer, C. D., \& Mercer, A. R. (1985). Teaching students with learning problems. Ohio: Charles E. Merril Publishing Co.

Montague, M., Jitendra, A.K. (2012). Researchbased mathematics instruction for students with learning disabilities. Dalam H. Forgasz \& F. Rivera (Eds.), Towards equity in mathematics education (pp. 381502). Heidelberg, Berlin: Springer.

National Council of Teachers of Mathematic (NCTM). (2000). Principle and standards for school mathematics. Reston, VA: NCTM.

Nieveen. (1999). Prototyping to reach product quality. London: Kluwer Academic Publisher. 


\section{Jurnal Riset Pendidikan Matematika, 3 (2), November 2016 - 161}

Ai Sadidah, Ariyadi Wijaya

Republik Indonesia. (2003). Undang-Undang RI Nomor 20 Tahun 2003, tentang Sistem Pendidikan Nasional.

Sulistyani, N., \& Retnawati, H. (2015). Pengembangan perangkat pembelajaran bangun ruang di SMP dengan pendekatan problem-based learning. Jurnal Riset Pendidikan Matematika, 2(2), 197 - 210. doi:http://dx.doi.org/10.21831/jrpm.v2i2. 7334

Sulistyowati, Y., \& Sugiman, S. (2016). Pengembangan perangkat pembelajaran bangun ruang di SMP dengan pendekatan creative problem solving. PYTHAGORAS: Jurnal Pendidikan Matematika, 9(2), 219-232. doi:http://dx.doi.org/10.21831/pg.v9i2.90 82

Thiagarajan, S., Semmel, D. S., \& Semmel, M. I. (1974). Instructional development for training teachers of exceptional children: A sourcebook. Blomington: may be ordered from the Council for Exceptional Children.

Van de Walle, J. A., Karp, K. S., \& BayWilliam, J.M. (2014). Elementary and middle school mathematics. New Jersey: Pearson.

Widoyoko, E.P. (2011). Evaluasi program pembelajaran, panduan praktis bagi pendidik dan calon pendidik. Yogyakarta: Pustaka Pelajar. 